\title{
REINTERPRETASI MUSTAHIQ AL-ZAKAH SEBAGAI SOLUSI PENGENTASAN KEMISKINAN
}

\author{
Samheri \\ STIU Al-Mujtama' Pamekasan \\ samheri.msh@gmail.com
}

\begin{abstract}
Abstrak: Penulisan karya tulis ilmiah berkenaan dengan zakat ini telah banyak dilakukan oleh banyak pakar, namun berdasarkan pengamatan penulis, masih belum ada tulisan yang mengkritisi sikap dan prilaku dan atau persepsi masyarakat tentang mustahiq al-zakah yang dianggap masih terlalu normatif dan konvensional, sehingga maqạsid shariah dari zakat itu belum terwujud. Oleh sebab itu, penulis merasa perlu melakukan reinterpretasi makna mustahiq al-zakah guna mencari solusi untuk mewujudkan tujuan pensyariatan zakat itu sendiri. Penelitian ini menggunakan metode penelitian kualitatif, dengan pendekatan fenomenologis. Penulis mencoba menyesuaikan dan mencari makna baru untuk mepreoritaskan mustahiq al-zakah yang lebih membutuhkan dan memerlukannya, seperti kata riqab yang tidak bisa ditemukan lagi dalam kehidupan nyata di pelbagai belahan bumi manapun. Juga pemaknaan sabîlillah dan ibnu sabil yang dianggap terlalu luas dan kurang relevan dengan maksud dan tujuan zakat, sehingga zakat belum terasa memberikan solusi bagi mustahiq yang sebenarnya. Selain itu, peruntukan zakat bagi muallaf dipandang kurang perlu, mengingat yang masuk Islam saat ini bukanlah orang yang lemah yang memerlukan bantuan dana untuk memenuhi kebutuhan hidupnya. Hal itu juga pernah dilakukan oleh Umar bin Khattab semasa hidupnya.
\end{abstract}

Kata Kunci: Reinterpretasi, mustahiq zakah, maqāṣid shariāh

Abstract:The writing of scientific papers regarding the zakat has been writen by many experts, but based on the author's observation, there is no writing that criticizes the attitude and behavior and or public perception of mustahiq al-zakah which is considered still too normative and conventional, so the maqashid shariah of zakat has not rialized. Therefore, the writer need to reinterpret the meaning of mustahiq al-zakah to find a solution and realize the purpose of zakat legalities. This research uses qualitative research method, with phenomenological approach. The author tries to adjust and search for new meanings to prioritize mustahiq al-zakah that is more in need and need it, like the word riqab that can not be found anymore in real life in various hemispheres anywhere. Also meaning sabilillah and ibn sabil are considered too broad and less relevant to the intent and

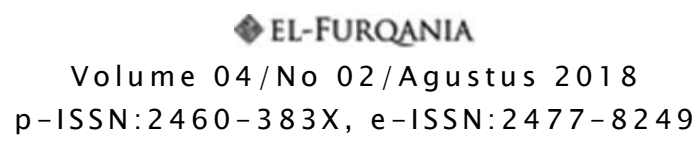


purpose of zakat, so zakat has not felt to provide a solution to the true mustahiq. In addition, the zakat allocation for converts is considered unnecessary, given that Islam is currently not a weak person who needs financial aid to meet the needs of his life. It was also be done by Umar bin Khattab during his life.

Keywords: reinterpret, mustahiq zakah, maqāṣid shariah

\section{Prolog}

Secara ekonomi, pelaksanaan pemungutan zakat semestinya dapat menghapus jarak perbedaan kekayaan yang mencolok serta dapat menciptakan redistribusi yang merata, di samping membantu mengekang laju inflasi. Selain perkembangan tak menentu dari peredaran mata uang di dalam negeri, kekurangan barang dan kecepatan peredaran uang, distribusi kekayaan yang tidak tepat dan tidak merata dapat pula mengakibatkan timbulnya laju inflasi. Penanganan yang tepat akan pajak zakat secara bertahap dapat menciptakan kondisi keseimbangan tata ekonomi seperti yang diinginkan. Oleh karenanya zakat didistribusikan pada mustahiq zakat sesuai syariat Islam.

\section{Problem Kemiskinan dan Mustahiq Zakat}

1. Kemiskinan Sebagai Masalah Sosial Ekonomi

Masalah kemiskinan dan pengangguran muncul dalam wacana teori ekonomi sebagai akibat dari ketidakpuasan terhadap kinerja teori-teori ekonomi dalam realitas pembangunan. Hasil-hasil pembangunan di sejumlah negara yang dicapai dengan menerapkan teori-teori yang ada selalu saja banyak menimbulkan anomali-anomali. terutama terhadap masalah pengangguran, kepincangan distribusi pendapatan, dan kesenjangan kesejahteraan. Singkat kata, teori ekonomi sejauh ini belum mampu secara optimal memecahkan masalah kemiskinin dan ketertinggalan.

Secara teoritis, kemiskinan merupakan akibat dari ketidaksesuain dalam praktek kebijakan ekonomi. Islam menganggap kegiatan ekonomi (pemanfaatan sumber produktif dengan pertimbangan efisiensi biaya dan oftimalisasi manfaat sosial) sebagai bagian atau salah satu aspek tanggung jawab sosial. Orang yang semakin banyak terlibat dalam kegiatan ekonomi akan semakin menjadi baik dalam hidupnya selama kehidupanya tetap terjaga keseimbanganya. Fungsi ekonomi sebagai bagian dari tangguang jawab sosial sangat diutamakan dalam Islam.

2. Zakat dan kedudukannya dalam Islam

Zakat merupakan salah satu instrumen dalam mengentaskan kemiskinan karena masih banyak lagi sumber-sumber dana yang bisa dikumpulkan seperti Infak, Sedekah, Wakaf, Wasiat, Hibah, dan lain 
sebagainya. Sumber-sumber tersebut merupakan pranata keagamaan yang memiliki kaitan secara fungsional dengan upaya pemecahan masalah kemiskinan dan kepincangan sosial. Dana yang berkumpul akan menjadi potensi besar dapat didayagunakan bagi upaya penyelamatan nasib puluhan rakyat miskin di Indonesia yang kurang dilindungi oleh sistem jaminan sosial yang terprogram dengan baik. ${ }^{1}$

Dana zakat yang dikelola dengan sistem dan menajemen yang amanah, professional dan integral dengan bimbingan dan pengawasan dari pemerintah dan masyarakat akan menjadi pemacu dan pemicu gerak ekonomi di dalam masyarakat dan menyehatkan tatanan sosial sehingga semakin berkurangnya kesenjangan antara kelompok masyarakat yang mampu dan kelompok yang kurang mampu. ${ }^{2}$

Zakat merupakan salah satu komponen dalam sistem kesejahteraan Islam. Apabila zakat benar-benar dikelola sebagaimana dicontohkan oleh Nabi saw, niscaya ia akan meningkatkan kesejahteraan masyarakat, mengurangi pengangguran, dan sekaligus mengurangi jumlah kaum fakir miskin. Apabila kesejahteraan masyarakat meningkat, sudah jelas kaum miskin secara berangsur-angsur akan berkurang. ${ }^{3}$

Tanpa merinci lebih jauh tentang zakat, jelas bahwa zakat dalam berbagai bentuknya berfungsi membangun pajak kekayaan negara, karena mendayagunakan semua bentuk kekayaan yang ada, seperti halnya dalam pajak modern, pengaturan pengumpulan zakat begitu sederhana dan tidak memerlukan pengetahuan khusus.

Patut dicatat bahwa zakat bukan merupakan sumber penerimaan biasa bagi negara-negara di dunia dan karena itu juga tak dianggap sebagai sumber pembiyaan utama. Negara bertanggung jawab dalam penghimpunan dan penggunaannya secara layak dan penghasilan dari zakat tidak boleh dicampur dengan penerimaan publik lainnya. ${ }^{4}$

\section{Urgensi Reinterpretasi Mustahiq Zakat}

Dalam sejarah Islam, sumber-sumber keuangan Islam yang diperoleh dari zakat, infaq, sedekah, dan wakaf (ZISWa) serta sumber sejenis lainnya telah terbukti selama ratusan bahkan ribuan tahun menjadikan Islam sebagai sebuah Negara super power. Selama tujuh abad, Islam mencapai puncak peradaban yang tiada duanya di Dunia. Philip K. Hitti misalnya membandingkan perbedaan kemajuan Islam dengan kemajuan Barat pada waktu itu, seperti jarak antara langit dan bumi.

\footnotetext{
${ }^{1}$ Umrotul Khasanah, Manajemen Zakat Modern, (Jakarta: Uin- Maliki Press,2010), cet $1 ., 38$

${ }^{2}$ Ibid. 39

${ }^{3}$ Ibid 52

${ }^{4}$ Mujar Ibnu Syarif, Fiqh Siyasah, (Jakarta, Erlangga, 2008), .331-332.
} 
Secara ekonomi, pelaksanaan pemungutan zakat semestinya dapat menghapus jarak perbedaan kekayaan yang mencolok serta dapat menciptakan redistribusi yang merata, di samping membantu mengekang laju inflasi. Selain perkembangan tak menentu dari peredaran mata uang di dalam negeri, kekurangan barang dan kecepatan peredaran uang, distribusi kekayaan yang tepat dan tidak merata dapat pula mengakibatkan timbulnya laju inflasi. Penanganan yang tepat akan pajak zakat secara bertahap dapat menciptakan kondisi keseimbangan tata ekonomi seperti yang diinginkan. ${ }^{5}$ oleh karenanya zakat didistribusikan pada mustahiq zakat sesuai syariat Islam.

Berdasarkan pengertian tersebut, visi zakat dirumuskan sebagai mengubah mustahiq menjadi muzakki. Visi ini menggariskan perolehan zakat yang bisa mengurangi jumlah fakir-miskin. Jika zakat sudah dibayarkan kepada fakir miskin dan mereka tetap menjadi fakir-miskin, berarti visi tersebut masih belum sempurna dijalankan. Oleh karena itu, dalam pengelolaan zakat diperlukan adanya amil yang produktif. Karena pendistribusian zakat pada hakikatnya itu merupakan tanggung jawab amil untuk mengurangi angka kemiskinan. ${ }^{6}$ Atas dasar itu, UU no. 23 tahun 2011, pasal 5 tentang pembentukan Badan Amil Zakat (BAZNAS) Untuk membantu melaksanakan pengelolaan zakat, ${ }^{7}$ serta menentukan targe-target kerja dengan tujuan mengurangi jumlah mustahiq. yang kemudian bisa metamorfose menjadi muzakkij. Jika semua telah berjalan sesuai rencana, maka tujuan zakat yang sebenarnya akan tercapai, yang secara otomatis para mustahiq akan berubah dan beralih status menjadi muzakkī pada tiga atau lima tahun berikutnya.

\section{Upaya Reinterpretasi Mustahiq al-Zakah}

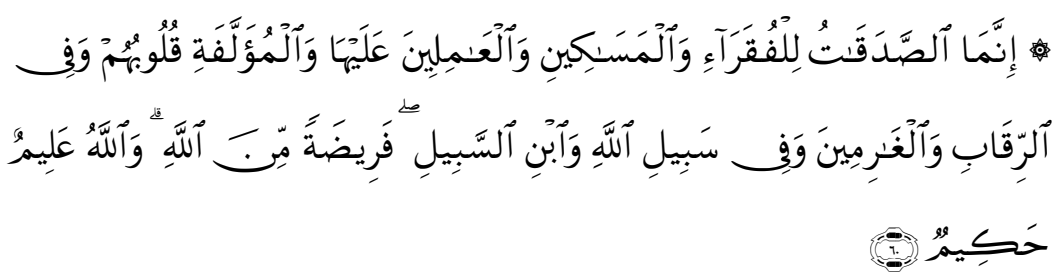

Dalam menetapkan golongan mustahiq zakat, para ulama berselisih pendapat dalam mendistribusikan dan mempreoritaskan di antara para

\footnotetext{
${ }^{5}$ Mujar ibnu syarif, Ibid, .331-332.

${ }^{6}$ Umrotul Khasanah, Manajemen Zakat Modern, (Jakarta: Uin- maliki press,2010), cet 1,53 .

7 www.hukumonline.com Badan Amil Zakat Nasional Pasal 5 Undang-undang republik Indonesia Nomor 23 tahun 2011 tentang Pengelolaan Zakat, 21
} 
mustahiq itu sendiri. Oleh sebab itu, penulis akan berusaha untuk memposisikan kedudukan para mustahiq sesuai dengan ketentuan dan preoritasnya berdasarkan bunyi surah al-Taubah ayat 60 yang akan dijelaskan sebagaimana berikut:

1. Fakir (الفتر)

Secara simantik, kata الفقراء berasal dari bahasa Arab yang merupakan

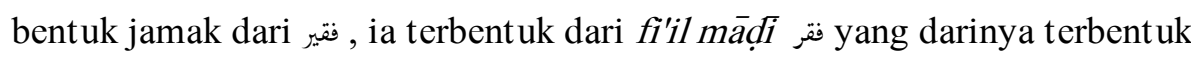
pula kata Iftaqara yang berarti membutuhkan. Maka, orang yang tidak mempunyai harta atau orang yang tidak mampu memenuhi kebutuhan hidupnya disebut dengan fakir, karena ia membutuhkah bantuan orang lain. ${ }^{8}$ atau bisa dikatakan orang fakir sebagai orang yang tidak mempunyai harta dan tidak mampu berusaha. Atau orang yang memiliki segelintir harta namun tidak mencukupinya.

Dalam Tafsìr Jalālain yang diterjemahkan oleh Bahrun Abu Bakar, beliau mengatakan bahwa Fakir adalah mereka yang tidak dapat menemukan peringkat ekonomi yang dapat mencukupi mereka. ${ }^{9}$ Begitu pula Tengku Muhammad Hasbi Ash Shiddieqy dalam bukunya Pedoman Zakat menjelaskan makna Fakir yaitu orang-orang yang memerlukan pertolongan karena tidak memiliki harta yang mencukupi untuk memenuhi kebutuhannya. Oleh sebab itu, zakat diberikan menurut keperluannya. ${ }^{10}$

Berdasarkan paparan data di atas, maka dapat disimpulkan bahwa orang fakir adalah orang yang tidak mempunyai harta, juga mereka yang tidak mempunyai usaha yang layak dalam kehidupan disebabkan karena ketidakmampuan mereka, maka dalam hal ini mereka digambarkan sebagai orang yang tua renta, sakit-sakitan, juga seorang diri, kalaupun ada keluarganya, dimungkinkan mereka juga seperti diri mereka, tidak mampu bekerja yang layak, sehingga mereka tidak bisa menutupi kebutuhan mereka. Oleh sebab itu, mereka berhak mendapatkan distribusi zakat itu, baik zakat fitrah maupun zakat mal.

\section{Miskin (المسكين)}

Menurut kajian kebahasaan, kata al-Miskin berasal dari kata sakana yang berarti diam atau tidak bergerak. Makna ini menggambarkan faktor yang menyebabkan kemiskinan yaitu tidak mau berusaha dan tidak mau berusaha dan bekerja. Berdasarkan makna ini, maka orang miskin adalah

\footnotetext{
${ }^{8}$ Kadar M. Yusuf, Tafsir ayat Ahkam : Tafsir tematik ayat-ayat hukum, (Jakarta: Amzah, 2013), cet 1,89.

${ }^{9}$ Imam Jalaluddin Al-Mahalli dan Imam Jalaluddin Al-Sayuti, terj. Bahrun Abu Bakar, Jilid 1, (Bandung: Sinar Baru Algesindo, 2008), 743.

10 Tengku Muhammad Hasbi Ash Shiddieqy, Pedoman Zakat (Semarang: PT. Pustaka Rizki Putra), 167.
} 
orang yang tidak dapat memenuhi kebutuhannya karena kurang usaha dan bekerja. $^{11}$

Sedangkan imam madzhab fikih berpendapat bahwa yang dimaksud miskin adalah mereka yang tidak mempunyai apapun, kecuali Imam Shāfii yang memerinci miskin. Menurut Imam Shāfïi bahwa miskin adalah orang yang memiliki harta dan atau usaha sebanyak seperdua kecukupannya atau lebih tetapi tidak sampai mencukupi kebutuhan hidupnya. Manakala yang dimaksud mencukupi kebutuhan hidupnya adalah standart umur manusia hidup rata-rata berumur 62 tahun, maka sesiapa yang mencukupi kebutuhannya semasa itu, berarti ia tidak boleh lagi diberikan zakat padanya, karena ia sudah dianggap mampu alias kaya. ${ }^{12}$

Berdasarkan paparan data di atas, maka peneliti menyimpulkan bahwa kata miskin diartikan seseorang yang memiliki harta dan atau pekerjaan, namun harta dan pekerjaannya tidak dapat memenuhi kebutuhannya. Dalam arti lain, miskin bukanlah orang yang berkeliling meminta-minta, melainkan mereka tidak memiliki sesuatu yang dapat menutupi kebutuhannya, dan tidak mampu bekerja untuk menutupi kebutuhannya tersebut, maka ia diberi bagian dalam distribusi zakat.

Dengan kata lain mereka tetap dikatakan sebagai orang yang tidak mempunyai apa-apa atau tidak mampu untuk memenuhi kebutuhannya yang layak. Oleh sebab itu, Islam memasukkan miskin pada para Mustahiq zakah (orang yang berhak menerima zakat), diharapkan mereka dapat memenuhi kebutuhan mereka dengan cara menerima pendistribusian zakat. Baik digunakan langsung atau baahkan dibuat usaha dengan pembagian harta zakat tersebut. Dengan demikian, akan terbentuk pemerataan kekayaan dan atau dapat meminimalisir jurang pemisah antara si kaya dan si miskin. Selain daripada itu, juga diharapkan, mereka yang asalnya menjadi Mustahiq pada tahun-tahun berikutnya mereka dapat bermetamorfose menjadi Muzakki al-zakah. Dengan demikian harta kekayaan tidak hanya berputar diantara orang-orang kaya diantara umat saja, sebagaimana difirmankan Allah dalam surah al-Hashr ayat 7 itu yang berbunyi: كَيْ لَ يَكُونَ دُولَةَ بَيْنَ الَْأَغْنِيكِ مِنْكُمْ

\footnotetext{
${ }^{11}$ Kadar M. Yusuf, Tafsìi ayat Ahkām : Tafsìir tematik ayat-ayat hukum, (Jakarta: Amzah, 2013), cet 1, 89.

${ }^{12}$ Sulaiman Rasjid, Fiqih Islam, (Bandung:Sinar Baru Algensindo,2004), cet 37, 213.
} 


\section{3. 'Amil (العاملين)}

Para 'Amil zakat adalah orang yang bekerja mengurus harta zakat, ${ }^{13}$ diperjelas oleh Ibnu Kathï bahwa yang dimaksud amil adalah mereka yang bertugas untuk menarik dan mengumpulkan zakat ${ }^{14}$.

Berdasar pada jasa mereka, maka mereka berhak mengambil sebagian harta zakat yang terkumpul sebagai jasa atau upah atas jerih payahnya mengelola harta zakat dari orang-orang mukmin yang berzakat. ${ }^{15}$ Ketentuan ini berlaku jika penguasa (pemerintah) tidak menggaji mereka dari baitul māl atau kas negara. Namun, jika pemerintah telah menggaji mereka secra tetap, semisal PNS/ASN, maka mereka boleh tidak diberi zakat lagi, sebab ketika sudah mendapat gaji, mereka otomatis tidak memiliki hak dalam zakat tersebut karena dianggap sudah mencukupi kebutuhannya itu. ${ }^{16}$

Harta yang diberikan kepada panitia adalah suatu bentuk dari bagian zakat itu sendiri. Oleh karena itu, ia juga termasuk harta zakat. Sedangkan harta zakat adalah harta pencucian, dan keluarga nabi tentu tidak pantas menerima harta pencucian karena stat us yang dimiliki mereka. ${ }^{17}$

Dari paparan di atas, maka dapat disimpulkan para Amil zakat yaitu mereka yang bertugas untuk menarik dan mengumpulkan zakat, juga menentukan siapa yang berhak, mencari mereka, membagi dan mengantarkannya kepada mereka, mereka adalah para wakil sekaligus para penerima zakat dari para pemberi, atas jasa ini mereka berhak mendapatkan bagian dari pada zakat yang terkumpul sebagai jasa atau upah atas jerih payahnya mengelola harta zakat dari orang-orang mukmin yang berzakat. Ketentuan ini berlaku jika penguasa (pemerintah) tidak menggaji mereka dari Baitul māl. Namun, jika pemerintah telah menggaji mereka, maka mereka boleh tidak diberi zakat lagi sebab ketika sudah mendapat gaji mereka otomatis tidak memiliki hak dalam zakat tersebut.

\section{Muallaf ( المؤلفة قلوبهم )}

Terdapat banyak pendapat dari kalangan Mufassir dan ulama' fikih dalam membahas peruntukan zakat bagi Muallaf, seperti Hasbi Ash-

\footnotetext{
${ }^{13}$ Kadar M. Yusuf, Tafsir ayat Ahkam : Tafsir tematik ayat-ayat hokum, (Jakarta: Amzah, 2013), cet 1,

14 Șafiyyurrahmān al-Mubārakfurì, Shahih Tafsìr Ibnu Kathïr jil 4,(Jakarta: Pustaka Ibnu Kathir, 2013), cet 8, 239.

15 Tengku Muhammad Hasbi Ash Shiddieqy, Pedoman Zakat (Semarang: PT. Pustaka Rizki Putra), 176.

${ }^{16}$ Tengku Muhammad Hasbi Ash Shiddieqy, Ibid,...177-179.

17 Syaikh Imam al-Qurthubi, al-Jami' Tì Ahkām al-Qur'ān, terj. Budi Rosyadi, Fathurrahman, Nashiulhaq, jil. 3 (Jakarta: Pustaka Azzam, 2008), h.432
} 
Shiddieqy mendefinisikan والمؤلفة قلوبهم sebagai orang yang ditarik hatinya untuk masuk Islam atau untuk memantapkan keislaman mereka. ${ }^{18}$ Imam Jalāluddin al-Mahalli dan Imam Jalāluddìn al-Ṣuyuțī menyatakan Muallaf sebagai seorang yang dibujuk hatinya supaya mau masuk Islam atau untuk memantapkan keislaman mereka, atau supaya mau masuk Islam orangorang yang semisal dengannya, atau supaya melindungi kaum muslim. ${ }^{19}$

Syaikh al-Qurtubi mengatakan bahwa yang dimaksud Muallaf dalam surah al-Taubah ayat 60 adalah segelintir orang yang hidup pada masa awal kemunculan Islam, yang baru memeluk Islam secara lahiriyah akan tetapi kekayaan mereka masih sangat lemah, oleh karenanya mereka diberikan zakat agar mereka tetap konsisten dengan keyakinan mereka, dan arena imannya masih lemah. ${ }^{20}$

Betapa pun ulama' sepakat bahwa sebagian kelompok atau jenis yang pernah diberikan sesuatu oleh Nabi. Kini tidak diberi lagi dengan alasan bahwa Islam sudah cukup kuat dan tidak membutuhkan mereka. keputusan ini pertama kali diterapkan dan dicetuskan oleh Umar bin Khatțāa ra. ${ }^{21}$

Umar mencegah pemberian zakat kepada para Muallaf di masa pemerintahan Abu Bakar dan di masa pemarintahannya, adakah dalam hal ini, Umar menyalahi hukum yang telah ditetapkan al-Qur'an? Bahkan dikuatkan juga dengan tindakan Rasulullah? Dan mengapa pula Abu Bakar dan para sahabat sepakat dengan pendapatnya? Tanpa ragu, kita katakan; bahwa Umar tidak menyalahi Al-Qur'an dan Rasulullah, karena pada masa pemerintahan Abu Bakar dan masa kekhalifahan sang khalifah kedua ini sudah tidak dijumpai lagi orang-orang yang layak disebut Al-Muallafatu Qulübuhum (orang-orang yang ditaklukan hatinya).

Kedudukan-kedudukan dan alasan ditetapkannya bagian-bagian tertentu untuk orang-orang Muallaf di masa Rasulullah dikarenakan Islam pada saat itu masih lemah, oleh karenanya zakat diberikan pada golongan Muallaf untuk menaklukan hati mereka. Akan tetapi setelah Rasulullah wafat, dan Islam tersebar di seluruh Semenanjung Arab, juga setelah orangorang Islam melalui ujian berat bertempur melawan kawan sendiri yang murtad, yang akhirnya dalam sekejab saja berakhir dengan bertempiarannya orang-orang murtad tersebut dan menyerah tanpa syarat kepada pasukan

\footnotetext{
18 Tengku Muhammad Hasbi Ash Shiddieqy, Pedoman Zakat (Semarang: PT. Pustaka Rizki Putra), 179.

${ }^{19}$ Imam Jalaluddin al-Mahalli dan Imam Jalaluddin al-Sayuti, terj. Bahrun Abu bakar, Jilid 1, (Bandung: Sinar Baru Algesindo, 2008), 744.

${ }^{20}$ Syaikh Imam al-Qurțubi, al-Jami' Ii Ahkām al-Qur'ān, terj. Budi Rosyadi, Fathurrahman, Nashiulhaq, jil. 3 (Jakarta: Pustaka Azzam, 2008), 434.

${ }^{21}$ M. Quraish Shihab, Tafsìr al-Misbah; Pesan, Kesan dan Keserasian al-Qur'ān, vol. 5, (Jakarta: Lentera hati, 2002), 598.
} 
Islam, semakin jelaslah dan terbukti bahwa kekuatan Islam adalah sangat luar biasa, suaranya bergema di seluruh Arab, dan gaungnya menggema kemana-mana sampai jauh keluar jazirah Arab, memenuhi ufuq dan menembus cakrawala. Jadi tidak diperlukannya lagi penghambur-hamburan perbendaharaan Negara untuk menarik simpati dan memujuk orang untuk masuk Islam. ${ }^{22}$

Inilah yang menjadi alasan mengapa Abu Bakar dan seluruh sahabat yang lain dengan secara sepontan sepakat menerima pendapat Umar, tanpa harus didahului adu hujjah terlebih dahulu. Karena mereka merasa diingatkan oleh Umar tentang hakikat Islam yang sekarang, yang sudah sangat kuat, tidak perlu lagi menghamburkan uang untuk menarik simpati orang non muslim. Sebagaimana yang dikatakannya dahulu, "Sesungguhnya Allah telah menjadikan Islam ini besar dan Berjaya. Kebenaran adalah dari Tuhan kalian, maka barangsiapa yang mau beriman, maka berimanlah, dan barangsiapa yang tidak mau beriman, maka kafirlah.”

Dan bagaimana mungkin, Islam masih harus membujuk-bujuk hati orang agar mau memeluknya, sedangkan pasukannya saja mampu menggetarkan dan memporak-porandakan kekuatan kuasa besar ketika itu, yaitu membayar Parsi dan Rom. ${ }^{23}$

Memang yang mengharapkan penerimanya masih banyak, tetapi itu bersyarat antara lain bahwa Islam membutuhkan mereka, pada saat Islam kuat dan tidak membutukan mereka lagi, maka gugurlah ketetapan hukum itu. Ini juga berdasar pada kaidah Ușul fiqh yang menyatakan bahwa ketetapan hukum selalu berkaitan dengan al-'illah (motif yang terukur), bila al-'illah itu ada, maka ketetapan hukum berlaku dan bila tidak ada, maka ketetapan hukum itu gugur. al-'illah dalam pemberian kepada Muallaf adalah kebutuhan Islam yang pada masa nabi kekuatannya belum semantap masa khalifah Umar ra. Dewasa ini jika dinilai bahwa Islam membutuhkan sekian macam orang yang diharapkan dapat mendukung perjuangan Islam, maka tidak ada halangan untuk menghidupkan ketentuan hukum itu lagi. Ini serupa dengan tradisi sementara penguasa yang menggunakan apa yang dinamakan dana taktis untuk keperluan memperlancar tugas-tugas yang diembannya itu. ${ }^{24}$

Dengan demikian, tidak diragukan lagi bahwa hukum tentang ada dan tidaknya orang-orang Muallaf, disesuaikan dengan situasi dan kedudukan yang ada di tengah-tengah masyarakat muslim. Kalau memang

\footnotetext{
${ }^{22}$ Muhammad Baltaji, Ijtihad 'Umar bin Khottob Dalam Penetapan Syariat Islam, terj. Abdul Rahman Saleh Siregar, (Selangor: Berlian Publications SDN. BHD, 2007), 194.

23 Ibid. 195

${ }^{24}$ M. Quraish Shihab, Tafsir al-Misbah; Pesan, Kesan dan Keserasian al-Qur'an, vol. 5, (Jakarta: Lentera hati, 2002), 598.
} 
diperlukan atau ada, maka ketika itulah hak-hak mereka diberikan, sebagaimana ditentukan dalam al-Qur'an. Akan tetapi, jikalau tidak ada atau sudah tidak diperlukan lagi, bagaimana mungkin harus dipakasakan? Dengan ini jelaslah, bahwa Umar, Abu Bakar dan juga para sahabatnya yang lain tidak menyalahi teks-teks al-Qur'an ataupun melanggar apa yang telah dilakukan Nabi. Karena apa yang mereka lakukan, tidak ada niat sedikitpun untuk mengenepikan ayat al-Qur'an atau bahkan menghapusnya. Mereka hanya menahan bagian yang sudah ada pemiliknya, yang hal itu tidak ada yang berhak menerimanya. Seandainya pada masa Umar, ataupun setelahnya ada kedudukan-kedudukan dan alasan yang memungkinkan dibagikannya bagian-bagian tersebut kepada yang berhak, tentu mereka akan mengeluarkan kepada pemilik-pemiliknya yang berhak.

\section{Riqāb (الرقاب)}

Menurut M. Quraisy Shihab, kata (الرقاب) al-Riqāb adalah bentuk jamak dari kata (رقبة) dimana lafaz raqabah pada mulanya berarti "leher" makna ini berkembang sehingga bermakna "hamba sahaya" karena tidak jarang hamba sahaya barasal dari tawanan perang yang saat ditawan, tangan mereka dibelenggu dengan mengikatnya ke leher mereka. ${ }^{25}$.

Islam adalah agama yang bijaksana. Oleh karenanya, Islam memberantas perbudakan dengan cara yang bijaksana pula (dihilangkan secara berangsur dengan cara memberikan sanksi-sanksi pelaku kejahatan besar kebanyakannya diminta untuk memerdekakan budak atau hamba sahaya, seperti membunuh orang yang tidak disengaja, men-zihār istrinya, dan lain sebagainya). Selain daripada itu, dalam rangka pembebasan budak, dalam sejarah peradaban Islam disediakan dana yang diambil dari zakat yang dipergunakan untuk membeli atau menebus budak dan membebaskannya atau diberikan kepada seorang budak yang telah mendapat jaminan dari pada tuannya untuk melepaskan dirinya dengan membayar sebanyak harta yang ditentukan. ${ }^{26}$ berdasarkan paparan data itu, maka dapat diketahui bahwa sistem peradaban Islam ini sudah sukses meminimalisir bahkan membasmi sistem perbudakan itu secara berangsur dan hasilnya dapat dilihat pada masa sekarang ini sudah tidak ada lagi perbudakan. Jadi tidak perlu lagi 'amil untuk mencari budak atau hamba sahaya untuk didistribusikan zakat pada mereka.

\footnotetext{
${ }^{25}$ M. Quraish Shihab, Tafsir al-Misbah; Pesan, Kesan dan Keserasian al-Qur'an, vol. 5, (Jakarta: Lentera hati, 2002), 598

${ }^{26}$ Kementerian Agama, Al-Qur'an dan Tafsirnya, juz 10, (Jakarta: Sinergi Pustaka Indonesia , 2012), 170.
} 


\section{Ghārim (الغارمين)}

Kata (الغارمين) adalah bentuk jamak dari kata (الغارم) Ghārim yakni "yang berhutang" atau dililit hutang sehingga tidak mampu membayarnya. ${ }^{27}$ baik mereka berhutang untuk kemaslahatan sendiri atau kemaslahatan orang lain, seperti mendamaikan golongan-golongan yang sedang berselisih ataupun terlibat konflik, atau kepentingan umum lainya, seperti membangun jembatan, masjid madrasah dan lainnya, jika mereka tidak lagi mampu unt uk mambayarnya. ${ }^{28}$ Walaupun yang bersangkutan memiliki kecukupan untuk kebutuhan hidupnya dan keluarganya. Namun orang tersebut bukan berutang untuk kepentingan pribadinya dan atau untuk bermaksiat kepada Allah swt. ${ }^{29}$ Juga bukanlah mereka yang berfoya-foya, apalagi menggunakan untuk kedurhakaan $^{30}$. Maka mereka berhak diberi zakat, untuk membayar hutanghutangnya.

Menurut madzhab Hanafi, ghärimīn adalah orang yang mempunyai hutang, sedangkan jumlah hartanya di luar hutang tidak cukup satu nișab, ia diberi zakat untuk membayar hutangnya. ${ }^{31}$

Menurut madzhab Maliki ghärimīn adalah orang yang berhutang, sedang hartanya tidak mencukupi untuk membayar hutangnya, hutang dibayar dari zakat, kalau dia berhutang bukan untuk sesuatu yang hasad (jahat).

Ketentuan hukum menyangkut al-Gharimin ini merupakan rahmat dan bantuan, baik untuk berhutang maupun yang memberinya, yakni baik untuk debitur maupun untuk kreditur. Maka dalam hal ini Islam dikatakan sebagai sistem kesetiakawanan sosial yang tidak menjatuhkan martabat manusia sebagai makhluk terhormat, tidak mengabaikan orang yang terpercaya dan tidak memperbolehkan sebagian orang memakan sebagian

\footnotetext{
${ }^{27}$ M. Quraish Shihab, Tafsir al-Misbah; Pesan, Kesan dan Keserasian al-Qur'an, vol. 5, (Jakarta: Lentera hati, 2002), 599. Syaikh Imam al-Qurthubi, Al-Jami' li Ahkām al-Qur'ān, terj. Budi Rosyadi, Fathurrahman, Nashiulhaq, jil. 3 (Jakarta: Pustaka Azzam, 2008), 446.

28 Tengku Muhammad Hasbi Ash Shiddieqy, Pedoman Zakat (Semarang: PT. Pustaka Rizki Putra), 185.

${ }^{29}$ Sayyid Qutub, Tafsir fỉ Dzilalil Qur'ān. Juz V.(tt), 370. Abu Ja'far Muhammad Bin Jarir ath-Thabari, Tafsir Ath-Thabari, terj. Abdul Somad dkk, jil. 12, (Jakarta: Pustaka Azzam, 2008), 895.

${ }^{30}$ M. Quraish Shihab, Tafsir al-Misbah; Pesan, Kesan dan Keserasian al-Qur'an, vol. 5, (Jakarta: Lentera hati, 2002),h.599

${ }^{31}$ Sulaiman Rasjid, Fiqih Islam, (Bandung:Sinar Baru Algensindo,2004), cet 37,h 215
} 
yang lain dalam sistem perundang-undangan, sebagaiman yang terjadi dalam syariat bumi dan syariat Islam. ${ }^{32}$

Berdasarkan pemaparan data di atas, maka dapat ditarik kesimpulan bahwa الغارمين yaitu orang yang mempunyai tanggungan hutang, baik dia berhutang untuk kepentingan dirinya sendiri maupun kepentingan umum atau orang yang mempunyai hutang karena bangkrut, seperti diceritakan Hasan bin Yahya dalam sebuah hadith yang menyebutkan bahwa orang itu bangkrut karena musibah banjir, maka golongan semacam itu boleh diberikan zakat. Namun situasi dan kondisi tidak sama antara dulu dan sekarang ini. Dimana kebanyakan orang-orang yang mempunyai hutang di zaman ini bukanlah mereka yang berhutang untuk memenuhi kehidupan mereka, juga bukan mereka yang berhutang karena bangkrut yang disebabkan oleh suatu musibah, akan tetapi mereka yang berhutang itu digunakan untuk sebuah bisnis, mereka yang sudah mempunyai jaminan untuk hutang mereka, sehingga walaupun mereka bangkrut akibat bisnis mereka, mereka masih lebih dari cukup untuk menghidupi keluarga dan juga diri mereka sendiri. Oleh karna itu, zakat tidaklah boleh dibagikan untuk golongan yang seperti itu, karna harta zakat pada dasarnya dikumpulkan dan dibagikan untuk mereka yang kesulitan dalam menjalani kehidupan karena mereka tidak dapat memenuhi kebutuhannya.

\section{Fï Sabīilliāh ( في سبيل الله)}

Pada dasarnya sabìilillāh itu dimaknai dengan Tariq al-Taqarrub ilā Allah (jalan mendekatkan (PDKT) diri kepada Allah swt. yang meliputi amalan kebajikan, baik amalan individual maupun amalan sosial. ${ }^{33}$

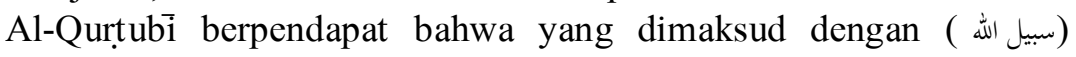
adalah "untuk jalan Allah" adalah para prajurit Islam yang berperang di jalan Allah dan para penjaga tapal batas daerah Islam. Mereka diberikan segala yang dibutuhkan untuk berperang beserta peralatannya tanpa memandang latar belakang mereka, apakah mereka itu orang kaya atau miskin, semuanya memiliki hak untuk diberikan bagian zakat. ${ }^{34}$ Hal itu dilakukan dengan tujuan untuk menolong agama Allah dan apa-apa yang mendukung prosesnya serta syarat-syariatnya yang telah disyariatkan Allah ke atas

\footnotetext{
${ }^{32}$ Sayyid Qutub, Tafsìr fì Zdilālil Qur'ān. Juz V.(tt), 370.

${ }^{33}$ Kadar M. Yusuf, Tafsir ayat Ahkam : Tafsir tematik ayat-ayat hokum, (Jakarta: Amzah, 2013), cet 1, 97.

34 Syaikh Imam al-Qurthubi, al-Jāmi' li Ahkām al-Qur'ān, terj. Budi Rosyadi, Fathurrahman, Nashiulhaq, jil. 3 (Jakarta: Pustaka Azzam, 2008), 451.
} 
hamba-hamba-Nya, yaitu dengan memerangi musuh-musuhnya, berperang melawan orang ingkar dan menentang ayat-ayat Allah. ${ }^{35}$

Berdasarkan penjelasan di atas, maka yang boleh dikatakan fi Sabỉlillāh adalah orang-orang yang dalam peperangan, sedang mereka tidak mendapatkan penghasilan dari jalan lain dan atau mereka tidak digaji oleh mana-mana pihak. Senada dengan pendapat di atas, apa yang dikatakan ulama madhhab fikih, seperti madzhab Imam Shāfi' $\bar{i}$, Hanafì, Hambali, maupun Malikỉ yang mendefinisikan makna fí Sabīlillăh sebagai bala tentara yang berperang di jalan Allah, sedang mereka tidak digaji oleh pemerintah atau suatu lembaga stertentu. ${ }^{36}$

Hal itu sesuai dengan apa yang diungkapkan dalam sebuah hadith nabi yang dijelaskan di dalam tafsir al-Ṭabari:

$$
\text { حدثني يونس فال اخبرنا ابن وهب قال: قال ابن زيد في قوله (وفي سبيل اله) قال : الغازي في سبيل }
$$

Dipahami oleh mayoritas ulama dalam tafsir Al-Misbah karya M. Quraisy Shihab sebagai arti para pejuang yang terlibat dalam peperangan, baik keterlibatannya seacara langsung maupun tidak langsung. Termasuk di dalamnya pembelian senjata. Pembangunan benteng dan lain-lain yang berhubungan dengan pertahanan negara. ${ }^{38}$

Di dalam tafsir An-Nur menyatakan sebuah pendapat yang berbeda dari penjelasan sebelumnya, dimana pengarang tafsir An-Nur itu menyatakan bahwa yang dimaksud dengan fí Sabilillāh ini tidak hanya untuk berbelanja keperluan para pejuang saja. Akan tetapi sebenarnya yang dikehendaki dengan fí Sabỉillāh adalah segala kemaslahatan umat dan segala rupa kebajikan untuk meningkatkan kesejahteraan masyarakat. ${ }^{39}$ Lebih tepatnya mereka menerima zakat untuk membiayai mereka (para pejuang) dan para pengawal perbatasan Negara atau membiaya pekerjaanpekerjaan kebajikan seperti untuk mengkafani jenazah, membangun jembatan, jalan, benteng dan masjid serta prasana-prasana umum lainnya,

\footnotetext{
${ }^{35}$ Abū Ja'far Muhammad bin Jarìr al-Ṭabarī, Tafsìir al-Tabarī, terj. Abdul Somad dkk, jil. 12, (Jakarta: Pustaka Azzam, 2008), 898-899

36 Sulaiman Rasjid, Fiqih Islam, (Bandung:Sinar Baru Algensindo,2004), cet 37, 213-214

${ }^{37}$ Abu Ja'far Muhammad Bin Jarir ath-Thabari, Tafsir Ath-Thabarì: Jamī'ul Bayan 'an Ta'wilil Qur'ān, (Hijr: tt). 527-528

${ }^{38}$ M. Quraish Shihab, Tafsir al-Misbah; Pesan, Kesan dan Keserasian al-Qur'ān, vol. 5, (Jakarta: Lentera hati, 2002),h.599

39 Tengku Muhammad Hasbi Ash Shiddieqy, Pedoman Zakat (Semarang: PT. Pustaka Rizki Putra), 189-190.
} 
seperti untuk membangun sekolah, rumah panti asuhan, rumah sakit dan sebagainya. ${ }^{40}$

Berdasarkan pemaparan data di atas, dapat ditarik beberapa kesimpulan bahwa makna fí Sabililläh adalah orang yang berperang serta berjuang di jalan Allah, membela serta menolong Islam dan meninggikan kalimat-Nya juga apa-apa yang menyokong prosesnya serta penerapan syariat Islam. Selain itu juga ditafsirkan bahwa makna sabilillah itu adalah bersifat umum, sehingga bisa diartikan segala kepentingan umat Islam yang sesuai dengan ajaran Islam, seperti pencari ilmu, pengajar ilmu agama, pembangunan masjid, sekolah dan lain sebagainya.

Oleh karena itu, dalam pembagian zakat golongan fakir, miskin itu lebih didahulukan karena memang tujuan turunnya ayat tentang Mustahiq zakat untuk meratakan kekayaan, agar harta tidak hanya berputar diantara orang yang kaya saja tetapi untuk mereka yang miskin, agar dalam Islam terdapat keseimbangan harta. Maka peneliti lebih cenderung memaknai kata fí Sabỉlillāh hanya dimaknai pada orang-orang yang berperang di jalan Allah, dan orang-orang seperti itu hanya ada pada masa Nabi, Sahabat, dan Tābi'in. mengingat saat ini di Madura sedang aman dan tidak dalam peperangan.

Dengan demikian, pengalokasian distribusi zakat yang diperuntukkan bagi Sabīililāh pada masa sekarang ini masih belum ada lagi dan perlu diprioritaskan kepada orang-orang fakir-miskin dan amil saja, sehingga zakat bisa mewujudkan tujuan zakat itu sendiri.

\section{Ibnu Sabīil (ابن السبيل)}

Syaikh Imam al-Qurțubì dalam Tafsìr al-Jāmi' li Aḥkāmi al-Qur'ān mengatakan Ibnu Sabīl adalah orang-orang yang melakukan perjalanan (Musāfir) jauh, terpisah dari negerinya, hartanya, dan keluarganya. penisbatan pada para Musafir dengan jalan, karena mereka selalu berada di perjalanan dan selalu melakukannya, ${ }^{41}$ maka orang yang seperti ini berhak menerima zakat, walaupun sebenarnya ia orang kaya di negeri asalnya, agar ia tidak perlu banyak berhutang karena kekurangan biaya sewaktu dalam perjalanan. $^{42}$

40 Tengku Muhammad Hasbi Ash Shiddieqy, Pedoman Zakat (Semarang: PT. Pustaka Rizki Putra), 191.

${ }^{41}$ Syaikh Imam al-Qurthubi, al-Jāmi' li Ahkām al-Qur'ān, terj. Budi Rosyadi dkk, jil. 8 (Jakarta: Pustaka Azzam, 2008), 455.

42 Syaikh Imam al-Qurthubi, al-Jāmi' li Ahkām al-Qur'ān, terj. Budi Rosyadi, Fathurrahman, Nashiulhaq, jil. 3 (Jakarta: Pustaka Azzam, 2008), 455; Abu Ja'far Muhammad Bin Jarir ath-Thabari, Tafsir Ath-Thabari, terj. Abdul Somad dkk, jil. 12, (Jakarta: Pustaka Azzam, 2008), .900; Abdullah bin Muhammad bin Abdurrahman bin Ishaq Alu Syaikh, Tafsïr Ibnu Katsir Jilid 4, (Jakarta: Pustaka 
Para ulama madzhab fikih, seperti Hanafi, Maliki, Hambali dan Syafi'i juga mengartikan Ibnu Sabỉl sebagai orang yang dalam perjalanan, kehabisan bekal, kehabisan biaya untuk ongkos pulang ke negerinya, maka orang ini diberi zakat untuk sekedar keperluannya. Dengan catatan bahwa ia memang membutuhkan bantuan perjalanannya itu pun bukan maksiat.

Di era modern ini, musäfir tidak lagi menjadi bagian dari para mustahiq zakat, dikarenakan pada zaman sekarang alat tranportasi dan komonikasi seperti handphone, ATM, mobil, sudah banyak digunakan untuk memudahkan pemenuhan kebutuhan muasafir itu sendiri, maka ketika seseorang berpergian, lalu dia kehabisan bekal makanan, ataupun uang, mereka tidak lagi harus menerima zakat, untuk keperluan mereka, karena mereka bisa menggunakan HP untuk menghubungi keluarganya, mereka bisa menggunakan ATM untuk mentransfer uang, mereka bisa menggunakan mobil ataupun kapal untuk perjalan jauh mereka, jika mereka seorang yang mampu atau kaya. dan jika mereka tidak mampu, maka mereka tetap berhak mendapatkan zakat, karena walaupun alat elektronik sudah canggih namun mereka tidak memilikinya karena tidak mampu, maka tetap saja keadaannya seperti musafir yang terdahulu.

\section{Epilog}

Berdasarkan paparan sebelumnya, maka para mustahiq zakat harus dipertimbangkan lagi, pertama seperti Riqāb dengan alasan, saat ini sudah tidak ada lagi sistem perbudakan di berbagai belahan bumi ini, kedua, muallaf, para muallaf di zaman sekarang sudah tidak lagi disebut sebagai orang yang lemah karena agama Islam sudah menjadi agama yang kuat dan Berjaya, ketiga, Gharimin, dalam kehidupan modern ini hampir setiap orang mempunyai hutang, namun mereka berhutang disebabkan karena bisnis atau usaha, sedang mereka termasuk orang yang kaya, keempat, sabïlillāh, di Negara Indonesia sudah tidak ada lagi perang, dan kelima, ibnu sabill, tidak lagi perlu menerima zakat, karena alat elektronik sudah canggih, seperti: mobil, Hp, ATM dan sebagainya.

Imam Syafi'i, 2008), 154; Departemen agama RI, Tafsìr Al-Qur'ān Al-Adzìm, (Jakarta: Lajnah Pentahih Mushaf al-Qur'an, 1985), 172; M. Quraish Shihab, Tafsir al-Misbah; Pesan, Kesan dan Keserasian al-Qur'ān, vol. 5, (Jakarta: Lentera hati, 2002), 601; Abdul Aziz Muhammad Azzam danAbdul Wahhab Sayyed Hawwas, Fiqih Ibadah: Thaharah, sholat, Zakat, Puasa, dan Haji, (Jakarta: Amzah, 2009) cet $1,418$. 


\section{Daftar Pustaka}

Agama, Departemen RI. Tafsìr Al-Qur'ān Al-Adzim, Jakarta: Lajnah Pentashih Mushaf al-Qur'an, 1985.

Agama, Kementerian. Al-Qur'an dan Tafsirnya, juz 10, Jakarta: Sinergi Pustaka Indonesia, 2012.

Alu Shaikh, Abdullah bin Muhammad bin Abdurrahman bin Ishāq. Tafsìr Ibnu Katsir Jilid 4, Jakarta: Pustaka Imam Syafi'i, 2008.

Baltaji, Muhammad. Ijtihàd 'Umar bin Khattāa dalam Penetapan Syariat Islam, terj. Abdul Rahman Saleh Siregar, Selangor: Berlian Publications SDN. BHD, 2007, cet 1.

Khasanah, Umrotul. Manajemen Zakat Modern, Jakarta: UIN-Maliki Press,2010, cet 1 .

Al-Mubārakfuri, Șafiyyurrahmān. Sahīh Tafsìr Ibnu Kathīr, jil 4, Jakarta: Pustaka Ibnu Kathir, 2013, cet 8.

Al-Qurțubì, Syaikh Imam. al-Jāmi' lì Ahkām al-Qur'ān, terj. Budi Rosyadi, Fathurrahman, Nashiulhaq, jil. 3 Jakarta: Pustaka Azzam, 2008.

Qutub, Sayyid. Tafsìir fí Zilāl al-Qur'ān. Juz V. Kairo: Dār al-Shurūq, 1992.

Rasjid, Sulaiman. Fiqih Islam, Bandung:Sinar Baru Algensindo, 2004.

Sayyed Hawwas, Abdul Aziz Muhammad Azzam dan Abdul Wahhab. Fiqih Ibadah: Thaharah, Sholat, Zakat, Puasa, dan Haji, Jakarta: Amzah, 2009 cet 1.

Shihab, M. Quraish. Tafsir al-Misbah; Pesan, Kesan dan Keserasian alQur'an, vol. 5, Jakarta: Lentera hati, 2002.

Syarif, Mujar Ibnu. Fikih Siyasah, Jakarta, Erlangga, 2008.

Ash Shiddieqy, Tengku Muhammad Hasbi. Pedoman Zakat Semarang: PT. Pustaka Rizki Putra.

Al-Suyūṭ̂i, Imam Jalāluddīn al-Mahallì dan Imām Jalāluddìn. Tafsìir Jalālain, terj. Bahrun Abu Bakar, Jilid 1, Bandung: Sinar Baru Algesindo, 2008.

Al-Ṭabarī, Abū Ja'far Muhammad bin Jarīr. Tafsir al-Thabari, terj. Abdul Somad dkk, jil. 12, Jakarta: Pustaka Azzam, 2008.

Yusuf, Kadar M. Tafsir Ayat Ahkam: Tafsir Tematik Ayat-ayat Hukum, Jakarta: Amzah, 2013, cet 1.

www.hukumonline.com, Badan Amil Zakat Nasional Pasal 5 Undangundang republik Indonesia Nomor 23 tahun 2011 tentang Pengelolaan Zakat, 21. 